\title{
Review
}

\section{Why stories matter: The political grammar of feminist theory}

\author{
Clare Hemmings \\ Duke University Press, Durham, UK, 2011, x+272 pp., £15.99/\$23.95, \\ ISBN: 978-0-8223-4916-7 \\ Contemporary Political Theory (2014) 13, e12-e14. doi:10.1057/cpt.2013.43
}

In this important book, Clare Hemmings analyses the stories feminist theorists tell when offering their accounts of four recent decades of transformation in academic feminism. In doing so, she illustrates the role that identity investments and affective attachments play in the development of feminist historiography. On Hemmings' reading, narratives that purport to describe the commonly accepted history of academic feminism are sites of contestation at which feminist theorists battle over who can lay claim to the position of the properly feminist subject and what constitutes appropriate feminist epistemology and research methods. Her work reveals to the reader the high stakes (both personally and professionally) associated with feminist storytelling.

Hemmings' analysis is grounded on her exhaustive reading of contemporary feminist theory. In preparation for the book, she read every article in every issue of six prominent feminist theory journals published between the years of 1998 and 2007. In addition, she read review essays and special issues in other social and cultural theory journals 'addressing the development of feminist theory or feminism' (p. 18). This comprehensive reading of recent feminist theory allows her to identify common narratives used to construct the competing accounts of academic feminism's past while foregrounding the important role academic journals play in authorizing new knowledge. The importance of feminist theory journals as communities of cocreation of feminist knowledge projects is further emphasized by her citation practice of 'de-authorization'. When quoting from theorists' articles, Hemmings notes the journal title and the year of publication, rather than the individual author. On her view, doing so 'emphasizes the role of journal communities ... in the establishment of feminist ... knowledge practices ... [and] provides a way of being able to focus on patterns across the journals, seeing them as a set, rather than being distracted by resonances across an individual oeuvre' (p. 21). Through the practice of deauthorization, Hemmings reminds the reader that each narrative's presumption of a commonly accepted history is not simply asserted by an individual author, but also implicitly (though perhaps ambivalently) endorsed by the journal of publication.

(C) 2014 Macmillan Publishers Ltd. 1470-8914 Contemporary Political Theory Vol. 13, 4, e12-e14 www.palgrave-journals.com/cpt/ 
Hemmings identifies three competing narratives that emerge from feminist theorists' retelling of recent feminist history. Each of these stories operates at a different affective register and assumes a differently situated feminist heroine. Furthermore, each narrative has epistemological implications and implicitly or explicitly endorses some modes of knowledge production over others. The three narratives - progress, loss and return - are in general agreement over the significant events in recent feminist history (that is, radical feminism, the politics of identity, the cultural turn), their periodization (in the decades of the 1970s, 1980s and 1990s, respectively) and the most significant figures (conflicting generational cohorts and especially the person of Judith Butler) (p. 133). However, the narratives differ with respect to their moral and political evaluations, their affective responses and their preferred visions of the shape of feminism to come. In progress narratives, the cultural turn is something to be celebrated, as the incorporation of post-structuralism into feminism served as a corrective to earlier essentialist and exclusionary feminisms and ushered in an era of increased sophistication, complexity and appreciation for difference (p. 56). Alternatively, in loss narratives, the cultural turn in feminist theory is something to be lamented, as it represents the abandonment of the radical tradition in favor of the increased professionalization of theorists, the institutionalization of women's studies and the prioritization of academic reputation and rank over addressing real women's problems in an increasingly hostile world (p. 85). Return narratives attempt to bring the two opposing groups - the younger generational cohorts of post-structuralist feminists and the older generational cohort of radical feminists - together in support of the common cause of revitalizing the feminist movement. Return narratives acknowledge and reject the supposed excesses of each position (that is, the retreat from empirical research and pragmatic concerns by post-structuralist feminist theorists and the essentialism and exclusions of earlier radical feminists) while attempting to retain the key insights and strengths of each position. In return narratives, a vital and reinvigorated feminist politics is possible if only feminist theorists put aside their differences with respect to the cultural turn and refocus their attention on the material conditions of women's lives (p. 101).

Throughout her account of the competing narratives that structure feminist theorists' stories about our shared, collective past, Hemmings illustrates the important role that Judith Butler plays in each story and the narrative function her reference performs. For Hemmings, Butler acts as a 'threshold' figure in that citations of Butler most often serve as the narrative marker of the break between feminism's radical past and the more recent post-structuralist period (p. 55). In each narrative, it is Butler who causes the discontinuity in feminist theory - although progress, loss and return narratives assign different valuation to the break. Hemmings' analysis of Butler's narrative function and her clear explanation of the what is at stake in the narratives' disagreement (that is, who gets to be the heroine of feminist theory) helps to explain the extreme affective reactions - from fawning adoration to hysterical vitriol - various feminists have had to Butler and her work. 
Hemmings' impressive work comes to its apex in the chapter 'Citation Tactics'. In this chapter, she examines the role that selective citation plays in the narrative construction of Butler as a threshold figure. She notes that in citation, Butler is frequently referenced along with Michel Foucault, creating an asymmetrical citational coupling between Butler and Foucault, in which Butler is treated as derivative of Foucault (p. 170). Yet, Hemmings points out, this citational coupling between Butler and Foucault depends upon the erasure of the influence of earlier feminist theorists on Butler's work (p. 182). She argues that coupling Butler and Foucault is crucial to maintaining the coherence of the narratives of progress, loss and return, in that these 'hetero-citational' and/or 'hom(m)o-citational' practices emphasizing Butler's intellectual indebtedness to a queer man facilitates her narrative construction as the disrupter of feminist theory (p. 178). Such citation practices place Butler outside of feminist theory and locate her within queer theory instead. Thus, Butler, post-structuralism and queer theory come to be understood as antagonistic to the tradition of radical feminist theorizing (p. 177).

Hemmings wants to avoid 'leav[ing] Butler stranded ... at the border of between poststructuralism and feminism ... parallel to, rather than overlapping, co-extensive, or emergent in dialogue with, feminism' (p. 179). To bring Butler back into the feminist fold, Hemmings engages in the textual practice of 'recitation', in which she re-cites Butler to link her more closely with Monique Wittig. In doing so, she emphasizes the influence of lesbian feminist thought on Butler's work, 'making visible what is, importantly, already there' (p. 180). This recitation allows the reader to see Butler as indebted to and emergent from the feminist theory tradition and destabilizes the narratives that depend upon Butler as an outsider and threshold figure for their coherence. Hemmings' recitation of Butler in conversation with Wittig is illuminating and demonstrates the partiality and limitations of any stories we might attempt to tell.

Hemmings, however, is less successful in her final chapter of the book, 'Affective Subjects'. In this chapter, she argues that disrupting the political grammar of feminist theory requires us to interrogate the subject of feminist theory. Here, she suggests examining the way in which the experience of feminist horror marks off the limits of acceptable feminist subjects and properly feminist judgments within Western feminist theory. The themes that were so carefully developed throughout the earlier chapters are less successfully integrated here. The chapter seems tacked on - a new tangent, rather than a conclusion. Although the chapter is less than satisfying as an endpoint for the book, it does seem to gesture toward what could be an interesting new project taking up the issue of feminist judgment. The final chapter is a distraction from an otherwise impressive and insightful book.

Kathleen Cole

Metropolitan State University, St. Paul, MN 55106, USA 